\title{
豚の才一エスキ一病
}

難 波 功 一*

オーエスキー病は Herpetoviridae の Alphaherpesvirinae に属する suid herpesvirus 1 によってひき起こさ れる急性伝染病である. 本病は 1902 年, ハンガリーの AUJESZKY が病性鑑定材料として持ち込まれた牛と犬の 脳を実験動物に接種したところ感染が成立し, 症状と病 変が狂犬病と異なることから独立した伝染病であること を認め，報告したのが最初である：以来，本病は世界的 にオーェスキー病と呼ばれているが, MAREK (1904)は 本病ウイルス感染の家鬼に対して球麻痺 (bulbar paralysis）といら名称を用いている. 北米では牛での症状が狂 犬病に似ているため仮性狂犬病 (pseudrabies) と呼ばれ ている，また，牛，羊，犬などの患畜は激しい搔痒を示 すことから， mad itch という名称も臨床家の間で古く から用いられている.

本病の自然発生は, 豚, 牛, 羊, 犬, 猫などの家畜で 多いが，本病ウイルスの宿生域は極めて広く，実験感染 を含めると多種類の哺乳類と鳥類が感染する．感染した 場合，豚以外の動物は急性経過をとって死亡する．豚で は日齢によって症状と経過が異なり，幼若なものほど重 篤な症状を示し，死亡率も高い，成豚は一般に不顕性感 染に終るが，ウイルスを体内に長期間保有し，再排泄す るために感染源となる。

本病は世界各地に分布して拉り，アメリカ合衆国，才 ランダ, フランス, イタリー, 北アイルランドならびに東 ヨーロッパ諸国での発生が特に多い. わが国でも本年 1

月から 2 月にかけて, 山形県下の一養豚場に拈いて発生 が認められた. 本病はひとたび常在化すると防疫が難し いが，わが国の場合，幸い侵入からの日が浅く陽性豚を 積極的に淘汰することで清浄化できるものと思われる.

\section{1. 発生国}

Animal Health Yearbook (FAO-WHO-OIE, 1978) によれば，現在発生のある国は，アメリカ合衆国，メキ シコ, ニカラグア, パナマ, キューバ, ハイチ, ブラジ ル，イギリス，北アイルランド，デンマーク，スエーデ ン, オランダ, ベルギー, フランス，西ドイッ，スイ ス，イタリー，スペイン，ポルトガル，ソ連，チェコス ロバキア，ハンガリー，ルーマニア，ブルガリア，ギリ

* 農林水産省家畜衛生試験場（荻城県筑波郡谷田部 町観音台3-1-1)
シャ, 東ドイツ, シンガポール, マレーシア, 台湾, タ イ，中国，ニュージランド，西サモアである，イラン， イラクの中東諸国でも過去に発生がある.

\section{2. 病原 ウイルス}

1) 性 状

ウイルス粒子の直径は150〜 $180 \mathrm{~nm}$ (REIssig and KAPLAN 1962), 浮上密度は $1.278 \mathrm{~g} / \mathrm{cm}^{3}$ (KAPLAN 1969) で, 162 個のカプソメアで構成される正 20 面体のカプシ ドは脂質を含んだェンベロープによって包まれている. 核酸は 2 本鎖の DNA (BEN-PoRAT and KAPLAN 1962; KAPLAN and Ben-Porat 1964) で, 分子量は $70 \times 10^{6}$, G-C 含量は 73\% (Russell and CRAwFord 1964) であ る. エチルエーテル (KAPLAN and VATTER 1959), クロ ロホルム (Pette and Mahnel 1964), フルオロカーボ ン (IvANICOVA 1961) に感受性で, 紫外線, X線によっ ても不活化される(KAPLAN 1962: PfEFFrKoRn ら 1965). 酸特よびアルカリに対しては比較的強く, $4^{\circ} \mathrm{C}$ では $\mathrm{pH}$ 5〜pH 9 で安定である (ZuFFA and SkodA 1962). 加 熱による不活化には, $56^{\circ} \mathrm{C} 15$ 分, $70^{\circ} \mathrm{C} 5$ 分, $100^{\circ} \mathrm{C}$ 1 分が必要である (ZuFfa and SkodA 1962). $44^{\circ} \mathrm{C} 5$ 時間の加熱では，28\%のウイルスが感染性を保持してい る(KAPLAN and VATTER 1959). $4^{\circ} \mathrm{C}$ 打よび $-30^{\circ} \mathrm{C}$ 以下

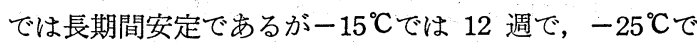
は $22^{\circ} \mathrm{C}$ の保存と同程度の速さで失活する (ZuFFA and SkodA 1962).

\section{2）培 養}

本ウイルスに感受性の高い細胞は, 豚腎 (SzENT-IVANY 1960)，ウサギ腎 (BARSKI ら 1955)，犬腎 (TORLONE 1958)，羊腎 (CECCARELL and DeL MAZzA 1958)，牛腎 (GAgLiardi 5 1960), 猫腎 (HoRvath and PAPP 1967), サル腎 (KeREKJARTo and RoHDE 1957), 馬腎 (PETRESCU 5 1969), フェレット腎 (BURROWs 1966), 䊿胎児 線維芽細胞 (Ivanovics 1955) などの初代培養細胞の他, PK-15, Hep 2, Vero (McFeran ら 1972), Hera (ScHERER and Syverton 1954), BHK-21 (Stoker and McPherson 1964), HmLu，CPK 細胞などの継代細胞 でもよく増殖する．細胞変性の特徵は円形化と多核巨細 胞の出現で, 時間が経過すると感染細胞は融解する。感 染細胞の核内には，八ローに囲まれた Feulgen 反応陽 性の封入体が認められる (REISSIG and KAPLAN 1962). 


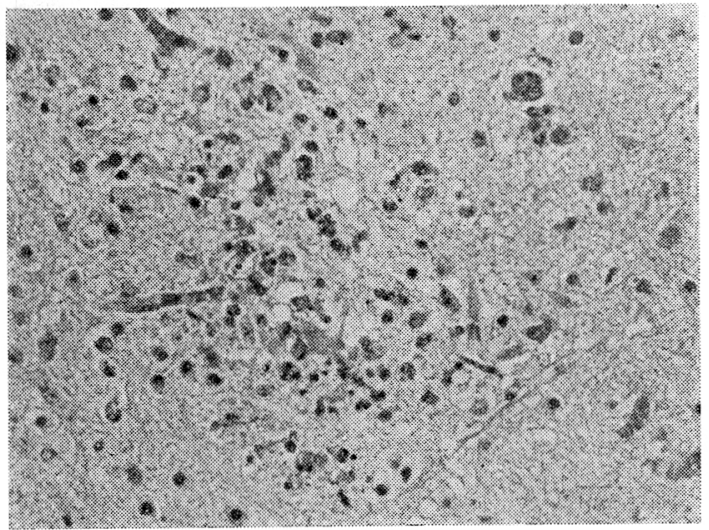

写真 1 変性した神経細胞を中心にグリア細胞集族 と好中球浸潤（延髄，豚，HE 染色， ×400）

ウイルス株によっては, 牛腎, 豚腎細胞では細胞变性効 果を認めず持続感染をとることもある (BELADI and BAKAy 1963; Kanitz and Gustafson 1969).

\section{3）血清 学 的性 状}

感染耐過豚は, 中和試験, ゲル内沈降反応, 補体結合 反応, 酵素免疫測定法などで検出される抗体を産生す る. 補体結合反応と䖝光抗体法で人ヘルペスシンプレッ クスウイルスとの間に共通抗原が認められている(TONEVA 1968). 中和抗体はエンベロープに存在するウイル スのグリコプロテインと反応する (MATtheW, R. E. F. 1978). 免疫学的に区別される血清型の存在は報告され ていない.

\section{4）宿主}

自然感染による発生は, 豚, 牛, 羊, 犬, 猫の他, キ ソネ (Bitsch and KNox 1971), ミンク (GEURden ら 1963; Terpstra 5 1962; LAPCEVIC 1964), 野ネズミ (LuKASHey and Rotov 1939), 野ウサギ(GRUNERT and SCODA 1964), 鹿(NIKolitsch 1954) で認められている. 実験的には, マウス, ラット，モルモット，マスカラッ ト, ヤマアラシ，スカンク，アナグマ，ラクーン，ジヤ ッカル, フェレット, クロテン, ウマ, ロバ, ヤギ, コ 一モリ，ハリネズミ，オポッサム，リーサスモンキー, マーモセットモンキー, ニワトリ，アヒル，ガチョウ， 七面鳥，ハト，ノスリ，スズメなどで感染が成立する. チンパンジー, ヘビ, カメ, ヒキガェル, シラミは感染 しない, 人の感染例も報告されているが, 現在は疑しい とされている.

\section{3. 感染経路亡体内伝搬}

自然感染はウイルスを含んだ鼻汁の飛沫による呼吸器 感染が主であるが (SHOPE 1934), 口からも侵入する. ウイルスは初感染部位の鼻腔, 咽喉頭粘膜, 扁桃, つい でそれらに付属するリンパ節で増殖する（MCFERRAN

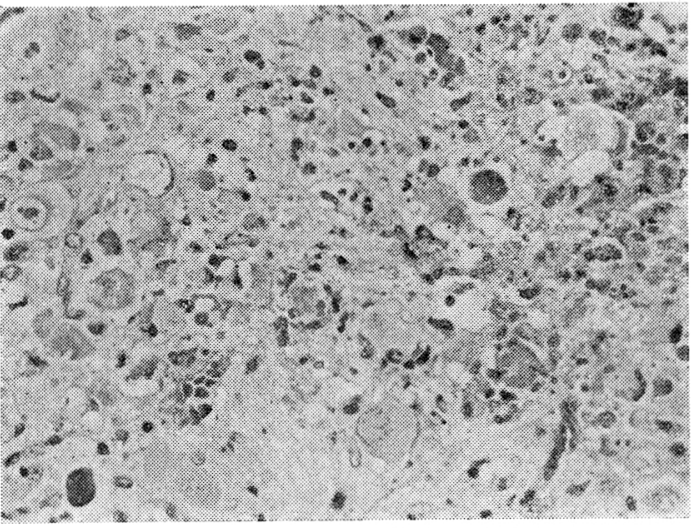

写真 2 神経節細胞の变性と巣状壊死

（三叉神経節，䀠，H E 染色， ×400）

and Dow 1965; RAJCANI and SABo 1969). 感染 1 日 後には, 鼻汁およびロ腔分泌液に多量のウイルスが排泄 される (MCFERRAN and Dow 1964). 上部気道で増殖 したウイルスは, 初感染部位に近い場所に分布する三叉 神経, 㖵覚神経, 舌咽喉神経などを介して中枢神経に到 達し，脳炎をひき抗こす (MCFERRAN and Dow 1965). ウイルスは脳春髅でよく增殖するが，䯣液中にウイルス が認められることは極めて少ない. いっぽう, 初感染部 位で増殖したウイルスの一部は, 吸入によって值接気管 支および肺に到達する，気道に病変をつくらないウイル ス株では, 初期には気管支粘膜で増殖し,ついで肺で増殖 する，親和性の強い株では, 急激に肺で増殖し, 広範囲な 肺炎をひき栄こす. 食道からもウイルスが検出されるこ とがあるが，腸管むで広がることは実験的に多量のウイ ルスを経口的に投与したときに限られる，肝，脾，腎か らもウイルスが分離されるが, 本病では一般にウイルス 血症が認められないために，このよらな器官へのウイル ス伝搬は白血球によると考光られている (BASKERVILLE 1971 a). しかし, 細胞で継代をくり返されたハンガリー

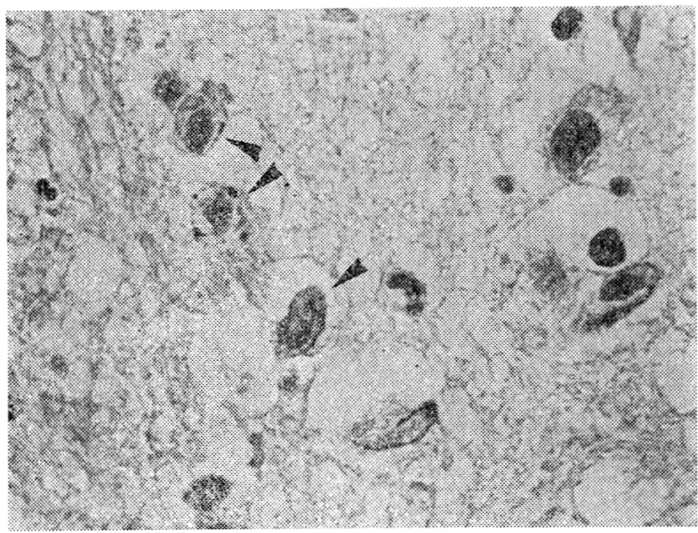

写真 3 グリア細胞に認められた好酸性核内封入体

（个）（延髄, 豚, $\mathrm{HE}$ 染色, $\times 1,000$ ) 


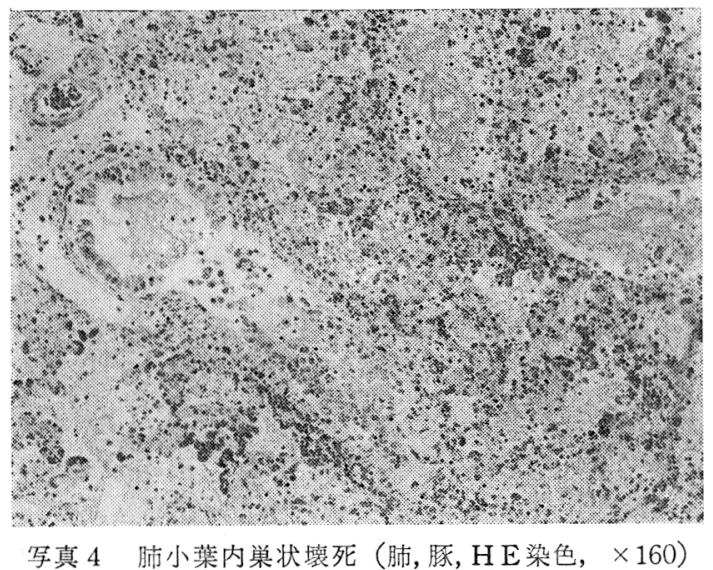

株特よびアイオワ株では，ウイルス血症が認められてい る。豚では創傷感染による自然発生は知られていない が，実験的に皮下あるいは䇗肉内にウイルスを接種する と, 接種部位㐨よび中枢神経からウイルスが回収される とともに感染が成立する. 病理学的検查でも創傷感染が 䈝われる例があり, 創傷感染は否定できない。

ウイルスの初感染部位から中枢神経への伝搬経路につ いては，子牛の実験でウイルスが軸索内を移動すること が証明されて特り，豚でも同じ経路が考克られている。

妊娠豚が感染した場合, 流死産が高率に2られるが, 胎児へのウイルス到達経路については交尾の之きに感染 したウイルスの持続感染あるいは白血球によって移動し たウイルスが胎盤で増殖し胎児へ伝搬することなどが考 克られているが，不明な点が多い。

\section{4. 臨床症状}

豚では日龄によって症状が異なり，一般に幼若な豚注 そ゚症状が重く,成豚では不顕性感染汇終ることが多い。し かし，1962年以降アメリカ合衆国では成豚をも発病死さ せる株が分離されている (HOWARTH ら 1968; SAUNDERS 5 1963，1964). 豚とネズミ以外の動物が感染すると, 搔痒症を示し，急性脳春䯣炎を起こし死亡する。

\section{1) 子 豚}

新生豚が感染した場合，36時間以内に嘔吐，下浰がみ られる.ついで, 沈うつ, ふる克, けいれん, 運動失調 などの神経症状を示した後, 虚脱状態に宿り死亡する。

発熱するが $41^{\circ} \mathrm{C}$ を越克ることはない, 白血球数は正常 值の範围にとどまる，死亡率はウイルス株によって異な るが 100\%汇近い，3〜4週路の子豚では，下痢は少な く便泌することが多い，死亡率は 40～60\% 低下し経 過が長くなる。

\section{2）肥 育 豚}

3 力月跉以上の豚は抵抗性が増し，発病率，死亡率と 与低下する。病勢は個体差，飼育環境，ウイルス株に上

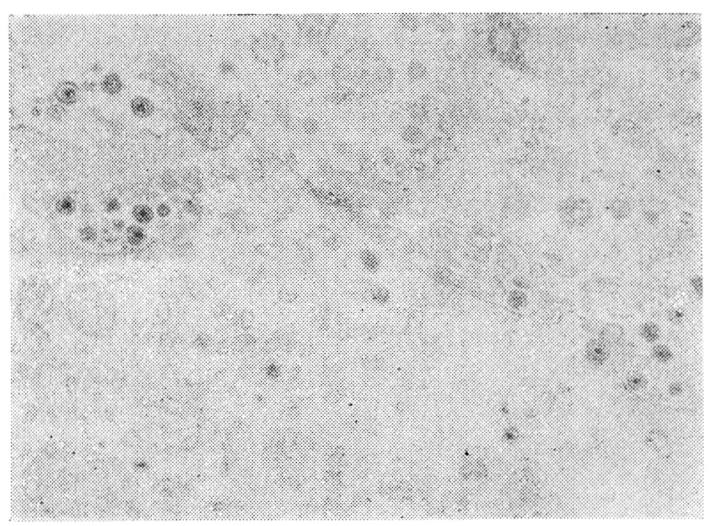

写真 5 細胞間の成熟ウイルス粒子 （気管支小皮細胞，豚， $\times 20,000 ）$

って異なるが数日の経過で耐過することが多いが不顕性 感染に終わることもある. 発症し, 死亡する豚では, 感 染 36 時間後には $40^{\circ} \mathrm{C}$ 以上の発熱がみられ, つづいて, せきなどの呼吸器症状や嘔吐, 便泌がみられる。やがて 元気食欲が消失し, らる党, 流涎が目立ち運動失調とな る. 後肢のバランスが乱れるため, ふらついて歩行す る. 病勢が進むと, 四肢の筋肉にけいれん, 強直を叔こ し歩行不能となり死亡する. 経過は普通 8 日間 位であ る.

\section{3）妊娠 豚}

約半数の豚が流産するが妊娠 1 カ月前後の豚ではとく 飞多い，妊娠後期に感染をうけたものでは黒子を媿出す る. 不顕性汇終わることが多いが, 発症例では, 発熱, 呼吸器症状, 食欲不娠, 便泌などがるられる(GORDON and LUKE 1955; MANTOVANI 1969). 神経症状を示し死 亡することはまれで㐫る。

\section{5. 病理}

\section{1) 肉 眼 病 变}

脳膜の充血, 脳春咀液の增量, 肺水腫, 気管支肺炎, 消化管粘膜拉よびリンパ節の充血之小出血, 腎被膜下の 点状出血などがみられるが，定型的なるのはない．

\section{2)組織病 変}

脳脊䯑道各部の灰白質乱よび白質, 三叉神経節おょび蓨 䯣神経節で神経細胞や神経節細胞の広範な変性と塙死, 血管周团性細胞浸潤, 神経膠細胞の限局性おょび, び漫 性增殖を特徵とした非化膿性脳脊㖪神経節炎が みられ る.しかし, 病変の程度には日零拉よび経過によって差 がみられる. 病変部の神経細胞, 神経膠細胞沶よび神経 節細胞飞はエオジン好性の核内封入体が認められ, 他の ウイルス性脳咨之の区別の指標となる(SHAHAN ら 1947; DONE 1957; Dow and MCFERRAN 1962).

肺水腫，細気管支炎，組織球性細胞の浸潤を伴う間質 
豚のオーエスキ一病

性肺炎ならびに肺小葉, 肝, 脾, 副腎, 扁桃の巣状壊死 もよく認められ，病変部の細胞には神経細胞と同様に核 内封入体が認められる. 自然感染例では, 化膿性鼻炎, 咽頭炎, 扁桃炎などの上部気道の病変もよくみられる (Csontos and Szeky 1966).

電子顕微鏡による検索では, 感染 1 ～ 6 日目にウイル ス粒子が神経細胞, 神経膠細胞, 神経節細胞, 平滑筋細 胞, 線維細胞, 気管支上皮細胞, 肺胞上皮細胞, リンパ 球, マクロファージ，網内皮細胞ならびに病変部の細胞 間腔陌で認められている (BASKERVILLE 1972, 1973).

\section{6. 診断}

牛, 羊, 犬, 猫などでは激しい搔痒症を示し, 死の帰 転をとるために臨床的に本病を疑うことができるが，豚 では呼吸器症状や全身症状を示すため, 臨床診断は難し い. 剖検所見も, 豚コレラ, パスツレラ症, 脳炎, 塩中 毒などと共通する.

病理組織学的検査は有用で, 上述の好酸性の核内封入 体の形成を伴う非化膿性脳脊髄神経節炎がみられる場合 には本病である確率が極めて高い。呼吸器の壞死性病変 と核内封入体が認められる時も同様に本病を疑うことが できるが，ウイルス株によっては認められないことがあ る.

確定診断にはウイルスおよび血清学的検査が必要で, 螢光抗体法抢よびウイルス中和試験が一般に用いられて いる. 螢光抗体法の術式は, 扁桃, 嗅球, 脳橋の乳剂あ

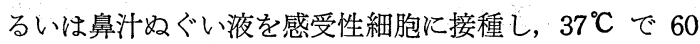

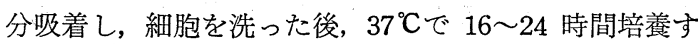
る.アセトンで 10 分間固定したのち，螢光標識抗体で 染色する. 陽性の場合には細胞質内に特異螢光が見られ る.

中和試験は，分離したウイルス材料を既知の免疫血清 で中和し，感受性細胞に対する細胞变性効果の抑制によ って判定する.

軽症例や不顕性感染例については, 中和試験による特 異抗体の出現上昇によって診断する. ゲル内沈降反応, 間接螢光抗体法も応用されているが前者は感度が劣り, 後者は診断例が多い場合には応用できない難点がある. 感受性細胞にウイルス材料を接種した場合, ヘルペス ウイルスの特徵的な細胞変性と HE 染色で好酸性の核内 封入体が認められる場合にも本病ウイルスを疑うことが できる.

扁桃, 肺, 脳橋, 嗅球などの $10 \%$ 乳剤をウサギに接 種すると本病の場合には搔痒症を示し死亡する.

実験室内診断ができない場合には，上記材料をドライ アイスあるいは液体チッ素で凍結し鑑定施設に送付す る. 凍結融解をくり返した材料や $-20^{\circ} \mathrm{C}$ に保存された 材料はウイルス分離に適さない.

\section{7. 疫学}

豚の間での感染の広がりは, 発症豚が排泄したウイル スの経鼻あるいは経口的侵入が主である. 本病も他の一 ルペスウイルス感染症と同様に, 潜在感染が成立し, 感 染耐過豚が間歇的にウイルスを再排泄するために，感染 耐過豚（抗体陽性豚）が感染源となることが知られてい る. とくに成豚では不顕性感染で耐過することが多く， 発症を認めずに広範囲に浸潤することが十分あり得る. 外国では豚から豚への感染だけでは説明し得ない発生例 が報告されて括り，野生動物がベクターとして考えられ ている.とりわけ，ネズミは豚についで本病ウイルスに 対して抵抗性があり，実験的にも長期間ウイルスを保有 するためにべクターとして有力視されている (NIKITIN 1960). しかし, 否定的な考えもある (MCFERRAN and Dow 1970). アメリカ合衆国ではアライグマが関与した と思われる発生例が報告されている. 実験的にも豚から アライグマ, アライグマから豚への感染は成立する. し かし, 豚以外の動物から豚への感染は全体の発生の中で は極めて少ないものと思われる.

\section{8. 免疫 とクチン}

本病の免疫機構については十分明らかにされていな い. 自然感染あるいは実験的に強毒ウイルスが感染し耐 過した豚は, 中和抗体が感染 7 日目ごろから上昇し, 約 1 力月後に最も高くなり長期間保有する (MCFERRAN and Dow 1973). このような豚は再感染にはよく抵抗 するが，鼻汁へのウイルス再排泄をしばしば扣こす。ウ イルス再排泄の機構については不明な点が多いが，気候 的要因や輸送がストレスとなって潜在感染していたウイ ルスが活性化し排泄されることが考えられている.

免疫母豚より生をれた子豚は初乳を介して移行抗体を 獲得する (KoJNOK and SurJan 1963; SkODA 5 1963). 移行抗体は10.8日の半減期で減少するが (ZuFFA 1964), 母豚の抗体価が高いときは, 子豚は高い抗体価を保有 し(ZuFFA 1963), 感染はしても発病することは少ない (Akkerman 5 1970; KojNok and Greczi 1957).

免疫豚の血清あるいはそのガンマグロブリンの投与 も，死亡率を低下させるが感染は阻止し得ない(KoJNOK and Greczi 1957; LuKashov and NikitiNa 1958).

これらのことから, 本病の感染防御には局所の細胞性 免疫あるいは分泌性抗体が重要な役割を演じて特り，血 清中和抗体は発病阻止あるいは体内でのウイルスの広が りを阻止する役割を演じているものと思われる.

不活化ワクチンの開発は, ウイルスの不活化法および アジュバントに至るなで詳細に検討されている.しか し，野外応用に満足し得るワクチンは今までのところみ られない。 
搦毒ワクチンは免疫能が優れているために, アメリカ 合衆国和よびョーロッパ諸国で用いられている.そのた め, ここでは代表的なワクチンウイルスについて簡単に 紹介する。

K株：ハンガリーで非常によく利用されている．野外 発生豚から分離したウイルスで，1回の鼻腔接種で死亡 率が低下するが感染防御は付与できない (BARTHA and KoJNoK 1963. a, b). しかし, 他の動物に対する安全性 は優れている.

ブカレスト株：ルーマニアで使用されている．強毒ウ イルスを漿尿膜で継代したウイルスで（BRAN ら 1963， 1965)，ワクチンには鶏卵でさらに 200 代継代されたも のが用いられている.このウイルス株の免疫効果は強い が (ANON 1965), ウサギ, モルモット, マウスに対して は病原性が極めて強く, 豚への応用は 9 日齢以上の子豚 と妊娠 2 力月までの豚に限られる.

TK 200 株と BUK 株：チェコスロバキアで使用さ れている．TK 200 株はブカレスト株を漿尿膜で 98 代 継代した後, 鶏胎児線維細胞で 200 代継代したウイルス (ZuFfA and PolAK 1965) で, BUK 株はブカレスト株 を漿尿膜継代の後, 鶏卵で 100 代さらに鶏胎児線維細胞 で 471〜621 代継代したウイルス (ScODA 1964)である. 両株とも豚に対しては安全であるが，他の動物に対する 病原性は強い(ZuFFA and DLHY 1964; JARMRICHOvA 1965). 発病阻止は可能であるが感染は阻止し得ない (Skoda 1962; SKoda 5 1964; SABo and GRunert 1971).

世界的によく用いられている弱毒ウイルスは以上であ るが, いずれのワクチンウイルスも感染防御が不可能な ため, キャリアー豚を作る危険性が極めて強い，そのた め, ワクチンによる防疫を行なっている国でも使用には 厳しい規制がなされている。

\section{9. 防疫}

本病では上述のように，感染耐過豚はすべて感染源と なり得るため，抗体陽性豚を導入しないことである.わ が国での発生もキャリアー豚によって持ち込まれたこと がその後の疫学調查で考学られている.

発生が認められたときは, 発病豚を淘汰し, ウイルス に污染した器具の使用を避け，ウイルスの拡散防止に配 慮する. 消毒には 1 〜 $2 \%$ のカイソーダを使うとよ い.

$$
\text { 文献 }
$$

1) Akkermans, J. P. W. M.: Neth. J. Vet. Sci., 3, 12 17 (1970)

2) Anon: Bull. Off. Int. Epizoot., 64, 267 296 (1965).

3) Baski, G., et al.: Ann. Inst. Pasteur, Paris., 89, 415 427 (1955).

4) Bartha, A. and Kojnok, J.: Proc. 17th Wld.
Vet. Congr. Hannover, 1, 531 533 (1963 a).

5) Bartha, A. and Kojnok, J.: Magy. Allatorv. Lap., 17, 321 323 (1963 b).

6) Baskerville, A.: PhD. Thesis, Queen's Univ., Belfast (1971).

7) Baskerville, A.: Res. Vet. Sci., 13, 127〜132 (1972).

8) Baskerville, A.: Res. Vet. Sci., 14, 229 233 (1973).

9) Beladi, I. and Bakay, M.: Acta Virol. Prague, 7, 477 (1963).

10) Ben-Porat, T. and Kaplan, A. S.: Virology, 16, 261 266 (1962).

11) Bitsch, V. and Knox, B.: Acta Vet. Scand., 12, 274 (1971).

12) Bran, L., et al.: Mh. Vet. Med., 18, 824 832 (1963).

13) Bran, L., et al.: Lucr. Inst. Cere. Vet. Bioprep. Pasteur, 2, 121 131 (1965).

14) Burrows, R.: Vet. Rec., 78, 769 770 (1966).

15) Ceccarelli, A. and Del Mazza, I.: Zooprofilassi, 13, 159 167 (1958).

16) Csontos, L. and Szeky, A.: Acta Vet. Hung., 16, 175 185 (1966).

17) Done, J. T.: Vet. Rec., 69, 1341 1353 (1957).

18) Dow, C. and McFerran, J. B.: Res. Vet. Sci., 3, 703 707 (1962).

19) Gagliardi, G., et al.: Atti Soc. Ital. Sci. Vet., 14, 703 707 (1960).

20) Geurden, L. M. G., et al.: Vlaams Diergeneesk. Tijdschr., 32, 36 (1963).

21) Gordon, W. A. M. and Luke, D.: Vet. Rec., 67, 591 597 (1955).

22) Grunert, Z. and Skoda, R.: Vet. Med. (Prague) 9, 351 (1964).

23) Howarth, J. A., et al.: J. Am. Vet. Med. Assoc., 152, $1114 \sim 1118$ (1968).

24) Horvath, Z. and PAPp, L.: Acta Vet. Hung., 17, $49 \sim 54$ (1967).

25) Huang, Shou-sen, and Cheng, Yu-chuan: Vet. Bull., 36, 641 (1966).

26) Ivanovics, G., et al.: Acta Microbiol. Hung., 3, 159 172 (1955).

27) Jamrichova, O. and Skoda, R.: Acta Virol. Prague, 13, 42 51 (1969).

28) Kanitz, C. L. and Gustafson, D. P.: Fedn Proc., 28, 697 (1969).

29) Kaplan, A. S.: Virology, 16, 305 313 (1962).

30) Kaplan, A. S. and Ben-Porat, T.: Virology, 23, 90 95 (1964).

31) Kaplan, A. S. and Vatter, A. E.: Virology, 7, 394 407 (1959).

32) Kerekjarto, B. and Rohde, B.: Z. Naturf, 12, 292 298 (1957).

33) Kojnok, J. and Greczi, E.: Acta Vet. Hung., 7, 
豚の才一エス

$423 \sim 427$ (1957).

34) Kojnok, J. and Surjan, J.: Acta Vet. Hung., 13, $111 \sim 118$ (1963).

35) Lapcevic, Von. E.: Deut. Tieraerztl. Wochschr., 71, 273 (1964).

36) Lukashov, I. I. and Nikitina, V. S.: Veterinariya (Moscow) 35, No. 9 (1958).

37) Lukashov, I. I. and Rotov, V. I.: Sov. Vet., 7, 51 (1939).

38) McFerran, J. B., et al.: Br. Vet. J., 128, 627 635 (1972).

39) McFerran, J. B. and Dow, C.: Res. Vet. Sci., 5, 405 410 (1964).

40) McFerran, J. B. and Dow, C.: Am. J. Vet. Res., 26, $631 \sim 635$ (1965).

41) McFerran, J. B. and Dow, C.: Br. Vet. J., 126, $173 \sim 179$ (1970).

42) Matthew, R. E. F.: Classification and Nomenclature of Virus (1978).

43) Mantovani, A.: Nuova Vet., 45, 175 184 (1969).

44) Nikitin, M. G.: Sb. Tr. Kharkov Vet. Inst., 24, 291 (1960).

45) Nrкоцiтsch, M.: Wien. Tieraerztl. Monatsschr., 41, 603 (1954).

46) Petrescu, A., et al.: Revueroum. Microbiol., 6, 301 305 (1969).

47) Pette, J. and Mahnel, H.: Berl. Münch. tierärztl. Wschr., 77, 313 319 (1964).

48) Pfefferkorn, E. R., et al.: Virology., 27, 457 459 (1965).

49) Reissig, M. and KAPlan, A. S.: Virology., 16, 1 8 (1962).

50) Russell, W. G. and Crawford, L. V.: Virology., 22, 288 (1964).

51) Saunders, J. R., et al.: Proc. U. S. Livest. Sanit.
Assoc., 67, 331 346 (1963).

52) Saunders, J. R. and Gustafion, D. P.: Proc. U. S. Livest. Sanit. Assoc., 68, 256 265 (1964).

53) SAbo, A. and Grunert, Z.: Acta Virol. Prague., 15, 87 94 (1971).

54) Schrer, W. F. and Syverton, J. T.: Am. J. Path., 30, 1057 1073 (1954).

55) Shahan, M. S., et al.: N. Am. Vet., 28, 511 521 (1947).

56) Shope, R. E.: Science, 80, 102 103 (1934).

57) Skoda, R.: Acta Virol. Prague., 6, 189 (1962).

58) Skoda, R., et al.: Acta Virol. Plague., 8, 1 9 (1964).

59) Skoda, R., et al.: Arch. Exp. Vet. Med., 17, 1363 $\sim 1370$ (1963).

60) Stoker, M. and Macpherson, I.: Nature (Lond) 203, 1355 1357 (1964).

61) Szent-Ivany, I.: Acta Microbiol. Hung., 7, 177 $\sim 178$ (1960).

62) Terpstra, J. I., et al.: Tijdschr. Diergeneek, 87, 1246 (1962).

63) Torlone, V.: Archo Vet. Ital., 9, 501 512 (1958).

64) Zuffa, A.: Arch. Exp. Vet. Med., 17, 595 613 (1963).

65) Zuffa, A.: Zentbtl. Bekt. Parasikde I. Orig., 192, $280 \sim 287$ (1964).

66) Zuffa, A. and Dlhy, V.: Veterinarstvi, 14, 241 243 (1964).

67) Zuffa, A. and Polak, V.: Bull. Off. Int. Epizoot., 64, 297 307 (1965).

68) Zuffa, A. and Skoda, R.: Vet. Cas., 9, 65 73 (1960).

69) Zuffa, A. and Skoda, R.: Vet. Cas., 11, 155 164 (1962). 